\title{
Green Marketing Practices: Its Antecedents and Impact on Quality in Indian Food Processing Industry
}

\author{
Farheen Mujeeb Khan
}

\begin{abstract}
Green marketing initiatives focus on the values and efforts that various companies incorporate into their marketing portfolio. This study analyses the green marketing process and practices prevalent in the food industry of India. Green marketing, along with greening the product and the firm by converting the 4Ps (price, product, promotion and place) of marketing into 4Ps of green marketing, involves a careful understanding of consumer preferences and purchase decision process. An in-depth review of the recent literature indicates that most of the aspects of green marketing align synergistically with the framework in the developed nations and, though it may appear to lag behind momentarily, it is catching-up quickly among Asian countries, including India. With the conscious-consumer at the helm, green marketing is increasingly viewed as a relevant marketing strategy in India towards sustainable development of the food industry. A questionnaire-based survey method was used for the data collection from food companies in India. The data were analyzed using exploratory factor analysis and confirmatory factor analysis was also performed. It was found after analysis that the green marketing practices were positively associated with the product quality. It was also found that the green marketing practices have a positive significant impact on the environmental preservation. Hence, it can be suggested that green marketing practices lead to environmental preservation. In the long-term, both the consumers and the food processing industry stand to benefit greatly from such green marketing initiatives and awareness but the policies and strategies need to be formulated and implemented accordingly.
\end{abstract}

Index Terms: Green Marketing Practices, Green Products, Food Processing Industry, Sustainable Development

\section{INTRODUCTION}

Environmental issues are one of the predominant challenges of the twenty-first century. To enumerate a few concerns these encompass global warming, climate change, natural resources depletion, pollution, toxic wastes, loss of biodiversity, acid rain, deforestation, agro-chemicals and poverty (Martens, 2014; Tietenberg \& Lewis 2016). These problems have also been intensified by rapid industrialization, urbanization, and population explosion. In a study carried out by the United Nations of the most environmentally polluted countries, India's ranking was a dismal seventh in the world (UNEP, 2011).

Environmental concern has grown into one of the chief issues world-wide. Increasing public awareness regarding environmental degradation, including pressures from

Revised Manuscript Received on August 25, 2019

Farheen Mujeeb Khan, IMS Unison University,

farheenk121@gmail.com environmentalist, Non-Governmental Organisations (NGOs) and the government has resulted in business incorporating green and environmental-friendly marketing in their organisations. Besides, traditional marketing has led to multiple environmental problems such as wastage, pollution, and deforestation, among others. Increasing consumers, exaggerated advertising, and unhealthy marketing tactics for customer attraction has exacerbated the issue.

The meaning of "green" in marketing lacks consensus, as it denotes varying practices and standards in distinct industries (Song-Turner, Courvisanos, \& Zeegers, 2014). Basically, green marketing incorporates traditional marketing practices, along with environmental advantages in the production, promotion, distribution, and pricing of product. A comprehensive and inclusive approach is required with respect to green marketing. A firm must exhibit dedication on diverse levels, such as production processes and environmental commitment, rather than focus only on the green attributes of the particular product.

An enterprising and vigorous food sector plays an important part in diversification of agriculture, enhancement of product shelf-life, employment creation, boosting farmer's income, and generation of an environment conducive for exports. By functioning as a link between agriculture and manufacturing, food processing industry has the capability to be a leading driver in India's economic growth in the future.

Green marketing in food processing sector has basic objectives such as to provide safe food to the consumers and present products of the highest quality, along with transforming food into a convenient and easy-to-consume form. Achieving green marketing in food processing industry will assist in addressing diverse developmental issues such as food insecurity, exportation problems, improved nutrition, and prevention of food wastages. The components of quality assurance and food standards are expected to aid the stakeholders, as well as, the small and medium enterprises (SME), food product exporters and importers, the government and regulatory bodies for setting food standards.

Green marketing, being a relatively newer concept in the Indian context, lacks significant research work in the area. This study attempts to address these gaps related to environmental marketing. One of the objectives of the study is to explore the impact of factors of green marketing practices being incorporated in the food companies.

Published By: 


\section{Green Marketing Practices: Its Antecedents and Impact on Quality in Indian Food Processing Industry}

\section{LITERATURE REVIEW}

Chiou, Chan, Lettice, and Chung (2011) observed that rising consideration for the environmental issues has led the government and the public to pressurize organisations into incorporating environment-friendly measures in their business operations. They have used empirical approach methodology and covered eight industry sectors in Taiwan. Results demonstrated that green suppliers and green innovations led to enhanced environmental performance and competitive advantage. L'Abbe et al. (2009) have pointed out in their conceptual study that collaboration among the government, food processers, and agricultural activities has positively influenced the ways in which the food sector has reformulated its products high in trans-fat in the North American market. Thus the food sector and the stakeholders involved have started transitioning towards healthier food options. Ramanathan, Black, Nath, and Muyldermans (2010) in their paper explored the influence of environmental regulations on innovation and business operations. Their sample selection comprised of a diverse range of industries from the United Kingdom. The methodology used in their study was empirical approach and data was analysed by structural equation modelling (SEM). The results indicated positive impact of environmental regulations on the business performance of firms. Traill et al. (2012) found that mandatory government regulations or voluntary alliances among food firms were required to implement effective product-labelling process focused on improving food safety. In their conceptual paper they have examined reformulation process in various European countries and the role played by the regulatory authorities of that nation in its implementation. The study was qualitative in approach and employed various case studies. Nath et al. (2014) stated that government and industry partnership were required for development of support infrastructures which were necessary to increase saleability of green products. Methodology used was Interpretive Structural Modelling (ISM) approach. Results indicated that low literacy rates, insufficient awareness, and unsatisfactory product performances were prime impediments in case adoption of green products by consumers. Chaudhuri, Srivastava, Srivastava, and Parveen (2016) found that food processing firms collaborating with suppliers, following best practices, and investing in modern technologies displayed positive outcomes, improved revenues, and increased profit margins. The methodology used was ISM approach. They studied food supply chain risk and concluded that recall of the food products from the market negatively impacts the firm's performance. In their study Mohanty and Prakash (2014) opined that in India, external stakeholders (such as the government regulators, competitors, and clients) pressurize the micro, small and medium enterprises (MSMEs) to adopt green practices. Faisal and Talib (2016) noticed that globalised food supply chains and increased consumer awareness about food safety have made traceability an important emerging issue in the food sector. They opined that for augmenting food traceability systems in India, management should focus on regulatory framework, food safety, quality, and certification process. Fraj, Martínez, and Matute (2011) reported that green marketing strategies lead to decreased production costs, enhanced efficiencies, and improved company's profitability. Hasnelly and Sari (2012) observed that competitive advantage can be achieved by green food companies through implementation of resource-based strategies. The methodology used was regression analysis. Saxena and Khandelwal (2012) were of the opinion that industries in India have a positive outlook for following green philosophy. They reported that there were concerns arising among Indian industries regarding environmental issues. They concluded that industries incorporating green initiatives in their marketing strategies believe they will gain competitive advantage by going green. Chahal, Dangwal, and Raina (2014) posited that a firm's green marketing strategy was facilitated by social marketing, relationship marketing, and marketing orientation. Furthermore, they argued that appropriate green marketing strategies can lead to increased product saleability and effective relationships with the consumers. Bossle, De Barcellos, and Vieira (2016) carried out a study on owners/directors/top managers (environmental section) of 581 Brazilian food companies that adopted eco-innovations. The methodology they implemented was regression analysis. They observed that eco-innovation contributed to environmental protection and improved performance of food companies. External factors such as governmental regulations and collaboration with stakeholders were found to be the major motivators for eco-innovation adoption, along with internal factors such as managerial concern for environment and human resource commitment. $\mathrm{Wu}$ and Lin (2014) noticed that by implementing green marketing strategies, organic farms in Taiwan were able to enhance their business performance and improve the product quality and corporate image. They surveyed 288 owners/CEOs of organic farms and structural equation modelling (SEM) methodology was applied to the data collected. They found that green marketing strategies enhanced environmental protection which led to effective business performance. The results also established that the Total Quality Management (TQM) was improved through aggressive implementation of green marketing strategies.

D'Souza et al. (2015) in their study of Australian manufacturing sector explored that businesses incorporating green marketing strategies positively influence green practices of their operations. Prakash (2002) in his conceptual paper identified that effective green marketing practices require upgrading the 4Ps (price, product, promotion, and place) of conventional marketing mix to include the green concept, along with diligent comprehension of public policy process. He focused on greening of the product, affordable pricing, and credible green claims. Kumar, Wright, and Singh (2011) selected 675 dairy household from three states of India. They used regression analysis and ordered-logistic regression analysis in the paper. Results stated that initially, higher costs were incurred by the farmers due to compliance with food safety practices. However, it was found that on selling milk, higher prices were realized by the farmers due to enhanced green food practices. 
They reported that the Indian government has undertaken an initiative known as the 'Clean Milk Production Scheme' towards ensuring milk safety and quality in the dairy supply chain. It was found by Kenneth et al. (2012) that adopting green practices leads to improved economic performance in manufacturing firms analysed by them in the study. Klikovac-Katanić and Kosanović (2012) attempted a study of food producers in Vojvodina (Italy) and used cross-sectional quantitative research design for the empirical analysis. The researchers assessed eco-marketing practices implemented by the producers and their knowledge regarding government regulations and international eco-standards. The results established that food manufacturers have modest knowledge regarding eco-marketing practices, but were willing to incorporate them in their companies. Liu, Kasturiratne, and Moizer (2012) proposed the hub and spoke integration model where they identified multiple direct pathways for the flow of resources (funds, information, and materials) between green marketing and sustainable supply chain management and this in turn assisted in enhancing business performance. They also performed empirical analysis and conducted a semi-structured interview of senior managers from 12 environment conscious companies. Sharma, Chandana, and Bhardwaj (2015) undertook a study to rank the indicators of performance which assisted in the implementation of green supply chain management in the Indian dairy sector. The results of analytic hierarchy process (AHP) approach showed that product quality, green purchasing, recycling, eco-friendly-transportation, green purchasing, and green manufacturing were main factors that were used for implementing green supply chain management.

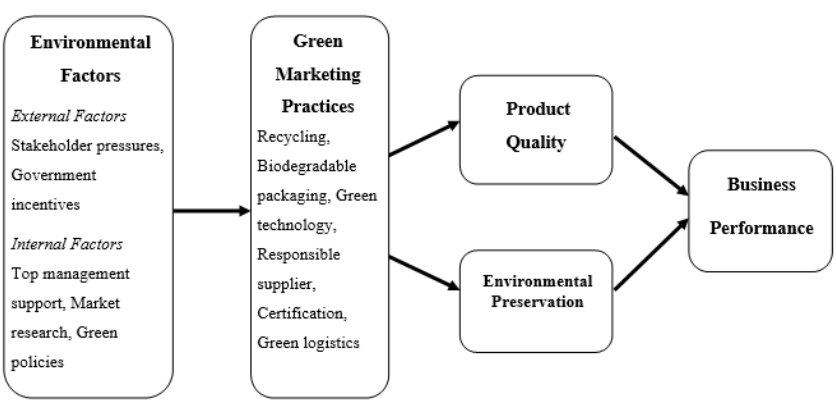

Fig. 1. Conceptual Model

Fuentes (2015) hypothesised in his ethnographic study of the Swedish food industry that green marketing was achieved through a complicated group of marketing procedures, such as, window dressing, decorating, and trail making, among others. Results identified that eco-products promotion was a performative undertaking which required artistic application. It was also found that green marketing was not a linear, logical, comfortably managed venture, but in fact a complicated, practice-based, and executable project. Bidyarthi et al. (2013) stated green marketing ensures sustained long-term growth, competitive advantage, cost effectiveness in production processes, enhanced performance, and access to new markets. Their analysis covered case studies of diverse Indian industries. Ghodeswar and Kumar (2015) surveyed 220 top and middle level marketing professionals and the sampling frame comprised Indian companies involved in green marketing practices. Green marketing practices that influenced green orientation were found to be eco-sourcing, product innovation, recycling process, green price, eco-advertising, and green communication. The researchers concluded that green product mix decreases negative environmental effect of the product and enhances quality. Lo and Shiah (2016) conducted a survey analysing responses from 174 electronic manufacturing firms. Regression analysis was carried out. The results showed that internal drivers (such as, company reputation, managerial support, third-party certificates, etc.) influenced the adoption of green practices. External drivers (like, government regulations, green suppliers, consumer expectations, competitor pressures etc.) also positively impacted the green practices adopted by the firm.

\section{RESEARCH METHODOLOGY}

The research design used in this study is descriptive in nature as it presents description of the green marketing practices which are being incorporated in the food industry. The research is also quantitative in nature as it is carried out by both primary and secondary data sources utilizing quantitative analytical methods. A synthesis of primary and secondary data is used to explore and accomplish the present research and test hypotheses. Primary data were collected from food processing firms located in Sonipat, New Delhi, Aligarh, and Lucknow cities of North Indian states, with the help of the questionnaire developed for the purposes of this study. Secondary data were collected through relevant public resources such as the National Sample Survey Organization (NSSO), Central Statistics Organisation (CSO), Agricultural and Processed Food Products Export Development Authority (APEDA), the Food and Agriculture Organization (FAO) of the United Nations, Food Safety and Standards Authority of India (FSSAI), online agricultural databases, journals, books, newspapers, previous studies on the subject, and seminar/conference proceedings.

\section{A. Constructs Measurement}

The constructs of the study were identified through exhaustive literature review, discussions with managers/owners of food firms, industry professionals, and subject experts. The items were measured on a 5-point Likert scale from strongly disagree (-2) to strongly agree $(+2)$.

The conceptual research model framework discussed in Fig. 1 has been proposed after exploratory research and thorough review of literature. Six latent constructs were identified, namely external environmental factors, internal environmental factors, green marketing practices, product quality, environmental preservation, and business performance. The relationships among these constructs are depicted in the hypothesized model.

\section{B. Questionnaire Development and Administration}

A questionnaire-based survey was designed and the questionnaire was framed after careful perusal of literature and discussions with four practising managers in the food industry and three academicians. 
The survey included closed-ended structured questions with a Likert-scale to elevate response rate. The questionnaire consisted of 36 items and had two sections.

Food industry was selected for the study and the target population for administration of the questionnaire was defined as firms engaged in manufacturing and marketing of processed food products in the northern part of India. Indian food sector is dominated by SMEs (Aggarwal \& Srivastava, 2016). Most of the microenterprises are in the unorganised sector (Panda, 2015). Therefore, our sample is limited to small, medium and large food enterprises as the micro enterprises usually lack the expertise and resources to confront environmental issues. The sampling frame comprised of firms engaged in manufacturing and marketing of processed food products in Sonipat, New Delhi, Aligarh and Lucknow. Two cities from Uttar Pradesh (Aligarh and Lucknow) with high concentration of firms involved in food processing were included in the study. Similarly, one city from Haryana (Sonipat) and the national capital of India, New Delhi, were selected because of the high number of food firms operating within their jurisdictions. Judgmental and convenience sampling processes were adopted for this study.

A pilot study was conducted and 20 executives of select companies were approached personally to complete the questionnaire to obtain feedback, modify, and screen it. It is important to note that questionnaire pretesting was performed to test their validity as three marketing professors were requested to review the questions for their accuracy and generalizability.

The final questionnaire was then personally administered to 350 marketing professionals at different food firms in Sonipat, New Delhi, Aligarh and Lucknow. The firms were selected from the directory of public sector and private sector companies. The survey was conducted from January 2017 to July 2017. Of the 350 questionnaires, seventy (20\%) were either incomplete, or inconsistent, or non-responsive and therefore excluded from the study. Finally, only 280 questionnaires $(80 \%)$ were completed and analysed as part of the study. The SPSS for Windows statistical software package (Version 20.0; SPSS; Chicago, IL, USA) and AMOS 20.0 software was used for conducting all data analyses. A sample size of more than 250 respondents was targeted as these software are sensitive to small sample size (Tabachnick \& Fidell, 2001; Garson, 2008). Cronbach's coefficient alpha of all the constructs in the pilot test ranged from 0.82 to 0.96 . All the reliability values passed the conventional proposed cut-off of 0.70 (Nunnally, 1978). Table-I present the results.

Table- I: Reliability and Scale Statistics

\begin{tabular}{|c|l|c|c|}
\hline \multirow{2}{*}{ No. } & \multicolumn{3}{|c|}{ Reliability and Scale Statistics } \\
\cline { 2 - 4 } & \multicolumn{1}{|c|}{ Constructs } & $\begin{array}{c}\text { No. of } \\
\text { Items }\end{array}$ & $\begin{array}{c}\text { Cronbach } \\
\text { s Alpha }\end{array}$ \\
\hline 1. & External environmental factors & 4 & 0.922 \\
\hline 2. & Internal environmental factors & 4 & 0.959 \\
\hline 3. & Green marketing practices & 9 & 0.891 \\
\hline 4. & Product quality & 5 & 0.857 \\
\hline 5. & Environmental preservation & 4 & 0.880 \\
\hline 6. & Business performance & 10 & 0.911 \\
\hline
\end{tabular}

Content validity of the scales applied in the study is determined by their origins from the extant literature, discussions with executives of select companies, and academicians who reviewed the questionnaire and confirmed that it represented face validity, after minor revisions. Prior to data analysis, data cleaning and data inspection processes, like identifying outliers and adjusting missing values, were performed. Missing observations and other case-related issues such as accuracy of data input were taken care of. SPSS 20.0 was used to maintain the database and for performing data analyses. Data screening was performed using basic descriptive statistics such as frequency distributions to identify missing responses. Straight forward checks were used to detect values that were improperly coded or out-of-range (Hau, 2005).

\section{RESULT ANALYSIS}

\section{A. INSTRUMENT VALIDITY AND RELIABILITY}

- Exploratory Factor Analysis (EFA): The current study employed the Exploratory Factor Analysis (EFA) using SPSS 20.0. The present study performed Common Factor Analysis (also known as, Principal Axis Factoring, PAF), which measures variance among variables, taking Eigenvalues more than one as a criterion for identifying the number of factors obtained. Rotation of factors is considered preferably as it assists in defining the factors clearly and streamlines the factor structure while extracting and retaining a subset of factors for analysis (Hair et al., 2010). Significance of factor loading was taken at absolute value of 0.50 and this assisted in identifying the number of factors to be retained. Items which correlated 0.50 or greater were regarded significant (Hair et al., 2010). Items which correlated less than 0.50 were removed since they represented less than $25 \%$ of variance. The results of the EFA process are presented in Table-II. Six factors were extracted which aggregately described $61.89 \%$ of total variance. Items GMP7, PQ5, CA2, and CA4 were eliminated from the scale as they had factor loading of less than 0.5 . The remaining 32 items comprised factor loading greater than 0.5. Subsequently, the extracted constructs were labelled and used for further analyses. The sample adequacy for analysis verified by the Kaiser-Meyer-Olkin (KMO) measure was 0.931, which was above the satisfactory limit of 0.5 (Field, 2017). Bartlett's Test of Sphericity, chi-square $=7466.88, \mathrm{df}=630$, and $\mathrm{p}<0.001$ showed that correlation within the items was acceptable for EFA.

- Confirmatory Factor Analysis (CFA): Confirmatory Factor Analysis (CFA) using AMOS 20.0 was conducted to analyse how well the scale evaluates the concept through dimensionality and adequacy of items connected to the corresponding constructs, simultaneously (Anderson \& Gerbing, 1988; Hair et al., 2010). 
Confirmatory Factor Analysis (CFA) Measurement Model which depicts standardised loadings of scale items and assesses items retained by factor analysis on respective dimensions of external environmental factors, internal environmental factors, green marketing practices, product quality, environmental preservation, and business performance. All scale items demonstrated good factor loading $(>0.05)$. Hence, none of the items were dropped from the scale. The result obtained from the model test depicted a good fit with data. The value of Chi-square/degrees of freedom was calculated to be 2.057 , which was below the recommended value of 3.0 (Arbuckle, 2007). The RMSEA for the model was 0.062. Any value less than 0.08 presented a good model fit (Browne \& Cudeck, 1993). Other fit indices also suggested an acceptable model fit $(\mathrm{NFI}=0.915, \mathrm{CFI}=0.926, \mathrm{GFI}=0.838)$. More than $50 \%$ of the variances in the construct are explained by their corresponding items as Average Variance Extracted (AVE) of all six constructs was greater than suggested value of 0.50 , proving convergent validity of constructs (Hair et al., 2010). Composite reliabilities ranged from 0.858 to 0.959 , exceeding the suggested value of 0.70 (Bagozzi \& Yi, 1988). In order to assess discriminant validity, squared correlations $(R 2)$ of the paired constructs were compared with AVE of each construct (Fornell \& Larcker, 1981). Discriminant validity is considered adequate when each squared correlation between a pair of constructs is less than the AVE for each corresponding construct (Fornell \& Larcker, 1981). Except for business performance, the conditions were met, suggesting that each dimension shared more variance with its own item than it shared with the other.

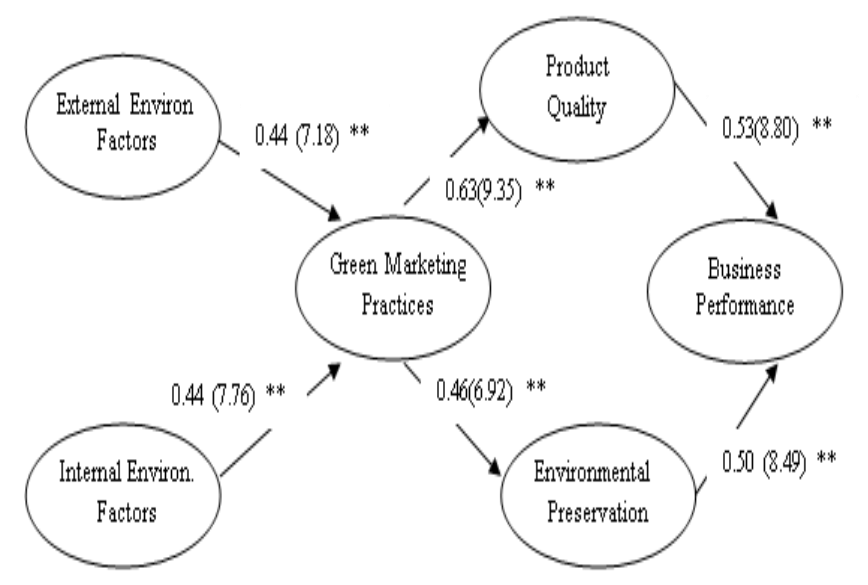

Fig. 2. Structural Model with Standardized Path Coefficients and C. R.
Table- II: Results of Exploratory Factor Analysis

\begin{tabular}{|c|c|c|c|c|}
\hline \multicolumn{2}{|c|}{ Converwers Items } & $\begin{array}{c}\text { Faraer } \\
\text { Lanfures }\end{array}$ & Variunce & $\begin{array}{l}\text { Figen } \\
\text { values }\end{array}$ \\
\hline \multicolumn{2}{|c|}{ EXTERNAL ENVIRONAIENTAL FACTORS } & & 39255 & 14.50 \\
\hline GRI & Government regularians require conequany to adopt green practioes & 0.913 & & \\
\hline GR2 & Governnet boentives motivate us to adopt green practices & 0.924 & & \\
\hline GR3 & Our cussomess roquire us tw adopt green practioss & 0.901 & & \\
\hline GR4 & Many of our competitesx have adopted grees practices & 0.724 & & \\
\hline \multicolumn{2}{|c|}{ INTERNAL ENVIRONMENTAL FACTORS } & & 6.727 & 2789 \\
\hline $\mathrm{CP1}$ & 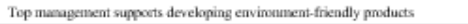 & 0.888 & & \\
\hline $\mathrm{CP} 2_{2}$ & Market research is conductid so detect green axeds & 0.871 & & \\
\hline CP3 & Green maricting is a phillosophy followed by our company & 0.954 & & \\
\hline CP4 & Managensent policies exist to minimize pollutioa & 0.981 & & \\
\hline \multicolumn{2}{|c|}{ GREZN ALARKETING PRACTICES } & & 5.919 & 2383 \\
\hline GMP1 & Our firm practioss recycling of waste & 0.776 & & \\
\hline GMP2 & Our fran uss reusable packaging material & 0.675 & & \\
\hline GMP3 & Our finn reduces the use of material in packaging & 0.673 & & \\
\hline GMP4 & Our finm uses sechnology for radocing enengy omsumptiog & 0.532 & & \\
\hline GMPS & Our firm purchases material which is saffety cettified & 0.696 & & \\
\hline GMPQ & Our prodxats have quality-price purity & 0.569 & & \\
\hline GMPS & 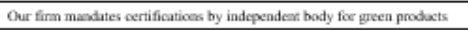 & 0.798 & & \\
\hline GMP9 & Our firm adopts eswianmental consideraxims in dessibution & 0.797 & & \\
\hline \multicolumn{2}{|c|}{ PRODUCT QUALITY } & & 4.750 & 2026 \\
\hline $\mathrm{PQ1}$ & The issue of prodact quality is wighly signifiomt at our firm & 0.684 & & \\
\hline $\mathrm{PQ2}$ & Issox of product safety is highly significant at our firm & 0.761 & & \\
\hline $\mathrm{PQ3}$ & Issue of product reliability is highly siguificant at ose firm & 0.812 & & \\
\hline $\mathrm{PQ} 4$ & 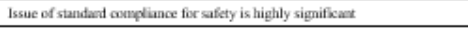 & 0.833 & & \\
\hline \multicolumn{2}{|c|}{ ENVIRONAENTAL PKESEKVATION } & & 3008 & 1.463 \\
\hline EP1 & 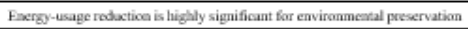 & 0.739 & & \\
\hline$E P_{2}$ & 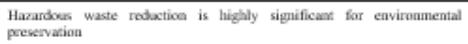 & 0.849 & & \\
\hline EP3 & $\begin{array}{l}\text { Reusable pachaging of products is highly significant for envirnamental } \\
\text { presenvaian }\end{array}$ & 0.811 & & \\
\hline EP4 & $\begin{array}{l}\text { Efficient waste treaturentidisposal methods are highly significant for } \\
\text { enviramental presevation }\end{array}$ & 0.822 & & \\
\hline \multicolumn{2}{|r|}{ BUSINESS PERFORAGANCE } & & 2.149 & 1.151 \\
\hline $\mathrm{CA}$ & Groen marketing coutributes to better corporate image & 0.748 & & \\
\hline $\mathrm{CA3}$ & Groen marketing coutributes to making produets competitive qulity-mise & 0.635 & & \\
\hline CAS & Green marketing coutributes to products enjoying pasitive ward-of-mouth & 0.776 & & \\
\hline$B P 1$ & Groen manketing contributes to iscrease in market share & 0.557 & & \\
\hline BP2 & Groen marketing contributes to inprovement in revenues & 0.853 & & \\
\hline BP3 & Groen marketing contributes to iacrease in cost saviags & 0.504 & & \\
\hline $\mathrm{BP4}$ & Green marketing coutributes to improved prodoxtivity & 0.664 & & \\
\hline BPS & 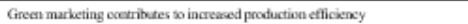 & 0.766 & & \\
\hline
\end{tabular}

\section{STRUCTURAL EQUATION MODELLING}

According to the established methodology of structural equation modelling, the variables identified should be categorised into exogenous and endogenous variables (Schreiber et al., 2006). External environmental factors and internal environmental factors were taken as exogenous or independent latent variable. Endogenous or dependent latent variable for the present study were green marketing practices, product quality, environmental preservation, and business performance. The proposed model was analysed to test the hypothesised relationships among the variables by structure equation modelling. The structural model was evaluated based on the model fit indices which indicate goodness of fit. The CMIN/DF is 2.366 which is below the suggested value of 3.0 (Kline, 1998). The RMSEA of the model is 0.070 which was also below the recommended value of 0.08 (Heene, Hilbert, \& Bühner, 2011), thereby showing that the data have a good fit with the model. Other fit indices also presented a good model fit as the values are within the acceptable limits $(\mathrm{NFI}=0.913, \mathrm{CFI}=0.902, \mathrm{GFI}=0.857)$. The validity of the hypothesised path was determined by examining statistical significance of structural dimension estimates. If the critical ratio (C. R.) is greater than 1.96 , then values are significant (Garson, 2008). The significant paths of the structural model with standardised path coefficients and C. R. values are presented in Fig 2. 


\section{Green Marketing Practices: Its Antecedents and Impact on Quality in Indian Food Processing Industry}

H01: There is no significant impact of external environmental factors on green marketing practices with regard to select food processing firms.

From the results, the relationship between external environmental factors and green marketing practices was found to be statistically significant $(\mathrm{C} . \mathrm{R} .=7.177)$. Furthermore, the standardised path coefficient value was 0.437 which is positive. This suggested that the external environmental factors have a positive significant impact on the green marketing practices. Hence, the null hypothesis is not supported while the alternate hypothesis is supported.

The results of the present study are in line with existing literature suggesting that external environmental factors positively impact green marketing practices (Bossle et al., 2016; Lo \& Shiah, 2016; Mohanty \& Prakash, 2014; Song-Turner et al., 2014). These studies have reported that governmental regulations, consumer demands, and competitor pressures, influence green practices.

Competition in the food industry can drive firms to develop new products which use less energy, less material, and are highly innovative. Marketers and policy-makers should formulate polices that provide incentives for green practices in the food industry, including financial incentives, training opportunities, and boost investments in the food sector. Government financial instruments for environmental protection and incentives for implementing pollution abating technologies should be promoted by the government. Such instruments include green tax, Capital Investment Subsidy Scheme (CISS), and National Clean Fund (NCF). The CISS provides financial

help to bio-fertilizer and agro-waste compost production units and assistance to implement quality control systems (NCOF, 2018). The NCF supports programs and projects which encourage clean energy technologies such as green transport, renewable energy, and waste management. Governmental regulations and frequent visits from law enforcement agencies are required in order for the food firms to increase their green practice adoption and implementation rates. Governmental agencies can also communicate policies wherein food firms adopting and complying with green practices would be subjected to fewer visits from regulatory agencies, thereby reducing unnecessary audits, hassles, and penalties.

$\mathbf{H}_{0}$ 2: There is no significant impact of internal environmental factors on green marketing practices with regard to select food processing firms.

From the structure equation modelling results, the relationship between internal environmental factors and green marketing practices was found to be statistically significant (C. R. = 7.763). Furthermore, the path coefficient value was 0.439 which is positive. This suggested that the internal environmental factors have a positive significant impact on the green marketing practices. Hence, the null hypothesis is not supported.

As regards the internal environmental factors, these results were also supported by the existing literature. Several studies have reported internal environmental factors positively impacting green practices (Bossle et al., 2016; Fraj-Andrés et al., 2009; Fraj et al., 2011; Mohanty \& Prakash, 2014; Song-Turner et al., 2014).

Internal environmental factors such as top management support, organisational green policies, and green market research leads to increase in green marketing implementation. Top management support can assist in compliance with international certifications and domestic quality standards to enhance product quality, promote CSR image, and oversee appropriate allocation of resources for implementing green practices. Increased expectation regarding favourable reputation of businesses leads to incorporation of green strategies by top-level management. Publication of periodic environmental reports, green forecasting, procedures, and policies for environmental protection and pollution abatement are necessary for effective execution of green marketing practices.

$\mathbf{H}_{0}$ 3: There is no significant impact of green marketing practices on product quality with regard to select food processing firms.

From the results, the relationship between green marketing practices and product quality was found to be statistically significant $(\mathrm{C} . \mathrm{R} .=9.353)$. The standardised path coefficient value was 0.628 which is positive. This suggested that the green marketing practices were positively associated with product quality. Hence, the null hypothesis is not supported while the alternate hypothesis is supported. It was also observed that green marketing practices lead to enhanced product quality which is supported by literature (Fraj et al., 2011; Fraj-Andrés et al., 2009; Wu \& Lin, 2014).

Hazard Analysis and Critical Control Points (HACCP), which is an internationally accepted food safety system, should be incorporated as a tool of quality assurance by the Indian food firms. Other food certification standards, mandated by the Food Safety and Standards Authority of India (FSSAI), should be diligently observed by food operators and voluntary certifications like the Bureau of Indian Standards (BIS) and agriculture mark (AGMARK) should also be accepted. Investments should be made in research and development $(\mathrm{R} \& \mathrm{D})$ centres and quality certification programs by the government and food firms as they assist in improving product quality and safety.

$\mathbf{H}_{\mathbf{0}}$ 4: There is no significant impact of green marketing practices on environmental preservation with regard to select food processing firms.

From the results, the relationship between green marketing practices and environmental preservation was found to be statistically significant $($ C. R. = 6.922). Furthermore, the path coefficient value was 0.463 which is positive. This suggested that the green marketing practices have a positive significant impact on the environmental preservation. Hence, it can be said that green marketing practices lead to environmental preservation. The null hypothesis postulated is not supported

Green marketing practices resulting in environmental preservation is supported by some studies but a few researches have reported contradictory results. Some studies found that green marketing practices indirectly impacted environmental preservation (Fraj et al., 2011; Fraj et al., 2013; Wu \& Lin, 2014).

Appropriate allocation and management of resources should be practiced by food firms, such as designing green products where energy consumption is minimised, contaminating materials are substituted with sustainable materials, and recycled materials are utilised for minimizing pollution and greenhouse gases. Selecting green and clean transportation would contribute to environmental preservation, by minimizing fossil-fuel consumption, while utilizing alternative and clean energy sources such as wind, solar, and hydro. 
Government policies should include planning/designing effective ports, freight corridors, and waterways for utilising transport channels other than road transportation. Reverse logistics should be implemented to recover packaging material which can be reused, reduced, and recycled by food firms. Food firms which incorporate environmental preservation strategies can enhance their corporate social responsibility (CSR) image, enjoy new marketing opportunities, and shield their organizations and stakeholders from fines and litigations. For example, food companies can reduce energy consumption by replacing high wattage tube-lights with light emitting diode (LED) bulbs and installing solar panels. Filtration and waste treatment/management plants should be made mandatory in the food sector by the government and regulatory bodies. These plants treat solid, liquid, and gaseous discharge prior to their release into the environment. Subsidies should be provided by the government when SMEs purchase and implement environment-friendly gadgets, products, and processes. The policy-makers (through awareness programs/workshops) should enlighten the SME food operators about government subsidies available on alternative sources of energy, such as, solar panels, and wind turbines and educate them regarding benefits of replacing high energy consuming lights with LEDs, importance of waste treatment plants, and reusable packaging of products. The food firms should focus on proactive pollution prevention processes, rather than end-of-process approaches.

$\mathbf{H}_{\mathbf{0}}$ 5: There is no significant impact of product quality on business performance with regard to select food processing firms.

From the results, the relationship between product quality and business performance was found to be statistically significant $(\mathrm{C}$. R. $=8.802)$. Furthermore, the path coefficient value was 0.532 which is positive. This suggested that the product quality has a positive significant impact on the business performance. Hence, the null hypothesis is not supported while the alternate hypothesis is supported.

Better quality products promote customer satisfaction and repeat purchases leading to increased business performance. Food operators must view quality of products as a strategic instrument for enhancing business performance. Third-party certifications (TPC) are effective regulatory mechanisms in the agri-food sector as they involve verifying food firms' conformity to standards. TPC comprise certifying products and processes for food safety standards (e.g., Codex standards), food quality (HACCP), Good Management Practices (e.g., ISO 9000 standards), Good Agricultural Practices (GAP), environmental standards (e.g., ISO 14000 standards), environment-friendly procurement, and non-GMO product certifications. Therefore, TPCs are necessary for boosting quality of green foods, which will make the products competitive, assist in export of the products to international markets, and increase corporate image of the food firms while also raising its market share.

$\mathbf{H}_{\mathbf{0}} \mathbf{6}$ : There is no significant impact of environmental preservation on business performance with regard to select food processing firms.

From the results, the relationship between environmental preservation and business performance was found to be statistically significant $($ C. R. $=8.489)$. Furthermore, the standardised path coefficient value was 0.499 which is positive. This suggested that the environmental preservation has a positive significant impact on the business performance. Hence, the null hypothesis is not supported.

As regards environmental preservation, the results of the present study were found to be contrary to most of the existing literature on the subject. Although, studies have shown that environmental preservation leads to higher business performance (Fraj et al., 2013; Rao \& Holt, 2005; Wu \& Lin, 2014), a few studies have reported that environmental preservation negatively impacts business performance. This may be because of the extra cost incurred on the company as a result of incorporating pollution abating technologies. Some researches have also found that environmental preservation may not impact business performance directly (Pullman, Maloni, \& Carter, 2009).

Food firms striving for international recognition and competitive advantage should focus on investing in $\mathrm{R} \& \mathrm{D}$ and quality certifications. As explored by Rao and Holt (2005), firms should obtain environmental certifications (e.g. ISO 14000) which assist in pollution abatement, lower energy consumption, increasing competitiveness, exploring new market opportunities, and enhancing business performance while keeping the costs low.

\section{RESULT AND DISCUSSION}

This study deals with the proposed hypotheses relating to various dimensions of green marketing. In the present study, following findings were observed:

1) It was found after analysis that the green marketing practices were positively associated with the product quality.

2) It was also found that the green marketing practices have a positive significant impact on the environmental preservation. Hence, it can be suggested that green marketing practices lead to environmental preservation.

3) It was identified that the external environmental factors have a positive significant impact on the green marketing practices.

4) It was found that the internal environmental factors have a positive significant impact on the green marketing practices.

5) It was also identified that the product quality has a positive significant impact on the business performance.

6) It was also observed that the environmental preservation has a positive significant impact on the business performance.

7) It was found that green marketing practices lead to improved product quality and environmental preservation which would eventually assist in enhancing business performance.

8) The hypothesised model would help the food processing industry appreciate that adoption of green marketing practices leads to improvements in business performance, pollution reduction, and conservation of environment. 


\section{Green Marketing Practices: Its Antecedents and Impact on Quality in Indian Food Processing Industry}

9) It was further analysed from literature review that one of the main precautionary approach for food safety situation is the effective implementation of traceability, which is the ability to trace and authenticate each ingredient of a food product in the supply chain.

10) To meet global trade demands, India needs to improve the facilities for product testing, certification, accreditation and train and employ skilled personnel in these facilities. For the products to be accepted world-wide, a quality certification like Codex Alimentarius offers a collection of internationally recognized standards that the Indian food firms can also implement. Therefore, an up-gradation of Agmark standards to the internationally recognized Codex Alimentarius requirements (focusing on standards, codes, practices, guidelines, and recommendations) is necessary to ensure a higher quality of food products. Except for the food safety requirements covered under the FSS Act (2006), most of the green standards and regulations are not mandatory for the buyers or the sellers. Therefore, a compatible legal food framework is necessary and should be accordingly designed and implemented by the government regulatory bodies.

11) In a vast and diversified country like India, unless the government makes specific and stringent regulations and utilizes its authority to implement such regulations and standards, the concept of green marketing cannot uniformly be realized and enforced. The government should devise policy measures to educate the SMEs regarding marketing benefits related to green practices such as better image, satisfied customers, positive publicity for the organization, and saving the environment. This can lead the smaller firms to invest and incorporate green practices, such as, waste recycling, reusable packaging, material reduction, green technology, safety-certified suppliers, and green distribution into their marketing functions and business strategies.

Considering recent reckless food quality-related incidents in India, the findings of this study indicate that the food firms should seriously contemplate green practices integration in order to minimise liability cases, product recalls, and consumer boycotts. Apart from this, if a firm employs and implements green practices, it will also influence stakeholder perception, open new markets, achieve government/state financial support, and enjoy positive evaluations from the stakeholders. Future researchers can expand the scope of this study by including diverse industrial sectors and a larger sample size. The relationship between green marketing parameters is already explored in this study but an extensive research incorporating more green variables would generate larger data points and present a comprehensive picture of the industry.

\section{REFERENCES}

1. A. Chaudhuri, S. K. Srivastava, R. K. Srivastava, and Z. Parveen, "Risk propagation and its impact on performance in food processing supply chain," Journal of Modelling in Management, vol. 11, no. 2, pp. 660-693, 2016.

2. A. Kumar, I. A. Wright, and D. K. Singh, "Adoption of Food Safety Practices in Milk Production: Implications for Dairy Farmers in

India," Journal of International Food \& Agribusiness Marketing, vol. 23, no. 4, pp. 330-344, 2011.

3. A. P. Field, Discovering statistics using IBM SPSS statistics. Thousand Oaks, CA: SAGE Publications, 2017

4. A. Prakash, "Green marketing, public policy and managerial strategies," Business Strategy and the Environment, vol. 11, no. 5, pp 285-297, 2002.

5. B. G. Tabachnick, SAS for windows workbook for Tabachnick and Fidell, Using multivariate statistics, fourth edition. Boston, MA: Allyn and Bacon, 2001.

6. B. Ghodeswar and P. Kumar, "A Study of Green Marketing Practices in Indian Companies," Marketing and Consumer Behavior, pp. 991-1010, 2015.

7. C. D'souza, M. Taghian, G. Sullivan-Mort, and A. Gilmore, "An evaluation of the role of green marketing and a firm's internal practices for environmental sustainability," Journal of Strategic Marketing, vol 23, no. 7, pp. 600-615, 2015.

8. C. Fornell and D. F. Larcker, "Evaluating structural equation models with unobservable variables and measurement error", Journal of Marketing Research, vol. 18, p. 427, 1981.

9. C. Fuentes, "How green marketing works: Practices, materialities, and images," Scandinavian Journal of Management, vol. 31, no. 2, pp. 192-205, 2015.

10. D. Garson, "Structural Equation Modeling" from Statnotes: Topics in Multivariate Analysis, North Carolina State University, 2008, Retrieved May 25, 2016. http://faculty.chass.ncsu.edu/garson/pa765/statnote.html

11. D. Panda, "Growth determinants in small firms: drawing evidence from the Indian agro-industry," International Journal of Commerce and Management, vol. 25, no. 1, pp. 52-66, 2015.

12. E. Fraj, E. Martínez, and J. Matute, "Green marketing in B2B organisations: an empirical analysis from the natural-resource-based view of the firm," Journal of Business \& Industrial Marketing, vol. 28, no. 5, pp. 396-410, 2013.

13. E. Fraj, E. Martínez, and J. Matute, "Green marketing strategy and the firms performance: the moderating role of environmental culture," Journal of Strategic Marketing, vol. 19, no. 4, pp. 339-355, 2011

14. E. Fraj-Andrés, E. Martinez-Salinas, and J. Matute-Vallejo, "A Multidimensional Approach to the Influence of Environmental Marketing and Orientation on the Firm's Organizational Performance," Journal of Business Ethics, vol. 88, no. 2, pp. 263-286, 2009.

15. H. Chahal, R. Dangwal, and S. Raina, "Antecedents and consequences of strategic green marketing orientation," Journal of Global Responsibility, vol. 5, no. 2, pp. 338-362, 2014.

16. H. J. Bidyarthi, M. A. Dande, P. Kuchar, M. L. Herode, and N. Y. Kasliwal, "Surviving with paranoia through green and clean marketing in Indian FMCG sector," International Journal of Business Performance Management, vol. 14, no. 4, p. 386, 2013

17. H. Song-Turner, J. Courvisanos, and M. Zeegers, "Green Marketing the Chinese Way: Insights From a Medium-Sized High-Tech Daily Chemical Firm," Journal of Asia-Pacific Business, vol. 15, no. 2, pp 164-192, 2014

18. Hasnelly and H. Sari, "Resource Based View: Strategies of the Manager of Green Food Product Industry in Indonesia," Procedia - Social and Behavioral Sciences, vol. 57, pp. 346-351, 2012.

19. IBM Corporation Released 2011, IBM SPSS Statistics for Windows, Version 20.0, Armonk, NY: IBM Corp, 2011

20. J. B. Schreiber, A. Nora, F. K. Stage, E. A. Barlow, and J. King, "Reporting Structural Equation Modeling and Confirmatory Factor Analysis Results: A Review," The Journal of Educational Research, vol. 99, no. 6, pp. 323-338, 2006.

21. J. C. Anderson and D. W. Gerbing, "Structural equation modeling in practice: A review and recommended two-step approach.," Psychological Bulletin, vol. 103, no. 3, pp. 411-423, 1988

22. J. C. Nunnally, Psychometric theory: 2nd ed. New York: Mcgraw-Hill, 1978. 
23. J. F. Hair, Multivariate data analysis: a global perspective. Upper Saddle River: Pearson, 2010.

24. J. L. Arbuckle, Amos 16.0 Users Guide. Chicago: Marketing Department SPSS, 2007.

25. K. W. Green, P. J. Zelbst, J. Meacham, and V. S. Bhadauria, "Green supply chain management practices: impact on performance," Supply Chain Management: An International Journal, vol. 17, no. 3, pp. 290-305, 2012.

26. L. N. Hau, "Acquiring marketing knowledge through international joint ventures," thesis, 2005.

27. M. B. Bossle, M. D. D. Barcellos, and L. M. Vieira, "Why food companies go green? The determinant factors to adopt eco-innovations," British Food Journal, vol. 118, no. 6, pp. 1317-1333, 2016

28. M. B. Bossle, M. D. D. Barcellos, and L. M. Vieira, "Why food companies go green? The determinant factors to adopt eco-innovations," British Food Journal, vol. 118, no. 6, pp. 1317-1333, 2016.

29. M. E. Pullman, M. J. Maloni, and C. R. Carter, "Food For Thought: Social Versus Environmental Sustainability Practices And Performance Outcomes," Journal of Supply Chain Management, vol. 45, no. 4, pp. 38-54, 2009.

30. M. Heene, S. Hilbert, C. Draxler, M. Ziegler, and M. Bühner, "Masking misfit in confirmatory factor analysis by increasing unique variances: A cautionary note on the usefulness of cutoff values of fit indices.," Psychological Methods, vol. 16, no. 3, pp. 319-336, 2011.

31. M. N. Faisal and F. Talib, "Implementing traceability in Indian food-supply chains: An interpretive structural modeling approach," Journal of Foodservice Business Research, vol. 19, no. 2, pp. 171-196, 2016.

32. M. R. Labbé, S. Stender, C. M. Skeaff, Ghafoorunissa, and M. Tavella, "Approaches to removing trans fats from the food supply in industrialized and developing countries," European Journal of Clinical Nutrition, vol. 63, no. S2, 2009.

33. National Centre of Organic Farming (NCOF) (2018), Ministry of Agriculture, Government of India. Retrieved from http://ncof.dacnet.nic.in/\#

34. P. Rao and D. Holt, "Do green supply chains lead to competitiveness and economic performance?," International Journal of Operations \& Production Management, vol. 25, no. 9, pp. 898-916, 2005.

35. R. B. Kline, Principles and practice of structural equation modelling. New York, NY: Guilford, 1998.

36. R. Mohanty and A. Prakash, "Green supply chain management practices in India: an empirical study," Production Planning \& Control, vol. 25 , no. 16, pp. 1322-1337, 2014.

37. R. P. Bagozzi and Y. Yi, "On the Evaluation of Structural Equation Models," Journal of the Academy of Marketing Science, vol. 16, no. 1 , pp. 74-94, 1988

38. R. P. Saxena and P. K. Khandelwal, "Greening of industries for sustainable growth," International Journal of Social Economics, vol. 39, no. 8, pp. 551-586, 2012.

39. R. Ramanathan, A. Black, P. Nath, and L. Muyldermans, "Impact of environmental regulations on innovation and performance in the UK industrial sector," Management Decision, vol. 48, no. 10, pp. 1493-1513, 2010.

40. S. Aggarwal and M. K. Srivastava, "Towards a grounded view of collaboration in Indian agri-food supply chains," British Food Journal, vol. 118, no. 5, pp. 1085-1106, Mar 2016.

41. S. Liu, D. Kasturiratne, and J. Moizer, "A hub-and-spoke model for multi-dimensional integration of green marketing and sustainable supply chain management," Industrial Marketing Management, vol. 41, no. 4, pp. 581-588, 2012.

42. S. M. Lo and Y.-A. Shiah, "Associating the motivation with the practices of firms going green: the moderator role of environmental uncertainty," Supply Chain Management: An International Journal, vol. 21, no. 4, pp. 485-498, 2016.

43. S.-I. Wu and S.-R. Lin, "The effect of green marketing strategy on business performance: a study of organic farms in Taiwan," Total Quality Management \& Business Excellence, vol. 27, no. 1-2, pp. 141-156, 2014.

44. T. H. Tietenberg and L. Lewis, Environmental and natural resource economics. London: Routledge, Taylor \& Francis Group, 2016.

45. T.-Y. Chiou, H. K. Chan, F. Lettice, and S. H. Chung, "The influence of greening the suppliers and green innovation on environmental performance and competitive advantage in Taiwan," Transportation Research Part E: Logistics and Transportation Review, vol. 47, no. 6, pp. 822-836, 2011.

46. United Nations Environmental Programme (UNEP), "World Conservation Monitoring Centre", 2011, Available at www.unep-wcmc.org.

47. V. K. Sharma, P. Chandana, and A. Bhardwaj, "Critical factors analysis and its ranking for implementation of GSCM in Indian dairy industry," Journal of Manufacturing Technology Management, vol. 26, no. 6, pp. 911-922, 2015.

48. V. Klikovac-Katanic and N. Kosanovic, "Implementation of Eco-Marketing during the Export of Food Products from Vojvodina." Poljoprivreda i Sumarstvo, vol. 58, no. 2, pp. 97, 2012

49. V. Nath, R. Kumar, R. Agrawal, A. Gautam, and V. Sharma, "Impediments to Adoption of Green Products: An ISM Analysis," Journal of Promotion Management, vol. 20, no. 5, pp. 501-520, 2014.

50. W. B. Traill, T. Bech-Larsen, L. Gennaro, A. Koziol-Kozakowska, S Kuhn, and J. Wills, "Reformulation for healthier food: a qualitative assessment of alternative approaches in 2012", AAEA/EAAE Food Environment Symposium, May 30-31, Boston, 2012

51. W. J. M. Martens, Health and climate change: modelling the impacts of global warming and ozone depletion. Abington, Oxfordshire: Earthscan, 2014.

52. W. M. Browne and R. Cudeck, in K. A. Bollen and J. S. Long (eds.), Testing structural equation models. Newbury Park: Sage Publications, 1993.

\section{AUTHORS PROFILE}

Dr. Farheen Mujeeb Khan is working as Assistant Professor in the School of Management, IMS Unison University, Dehradun. She is also pursuing her Post-Doc from Indian Council of Social Science Research (ICSSR). Her areas of interest are Green Marketing and Sustainable Agribusiness Management. 